\title{
The Adhesion Molecule on Glia (AMOG) Incorporated into Lipid Vesicles Binds to Subpopulations of Neurons
}

\author{
Horst Antonicek and Melitta Schachner \\ Department of Neurobiology, University of Heidelberg, 6900 Heidelberg, FRG
}

To investigate the functional role of the novel adhesion molecule on glia (AMOG) in cell surface interactions, immunoaffinity-purified AMOG was incorporated into liposomes and measured for its ability to bind to cells in monolayer cultures. AMOG could be incorporated into liposomes in functionally active form after solubilization from membranes in $1 \%$ cholate buffer containing soybean lecithin, elution from the AMOG monoclonal antibody column with $4 \mathrm{M} \mathrm{MgCl}$, containing $1 \%$ octylglucoside, and removal of detergent for liposome incorporation by gel filtration. AMOG-containing liposomes bound to neurons, but not to oligodendrocytes, astrocytes, or fibroblasts in early postnatal cerebellar cultures. AMOG-containing liposomes also bound to the pheochromocytoma cell line PC12, but not to neurons in cultures of spinal cord and dorsal root ganglia after various times in vitro. Fab fragments of monoclonal AMOG antibodies, but not of L3 monoclonal antibodies directed against a carbohydrate structure on AMOG, inhibited binding of liposomes. Liposome binding was not reduced by preincubation of cerebellar cells with antibodies to AMOG, to the neuron adhesion molecule L1, the neural cell adhesion molecule N-CAM, or the L3 carbohydrate structure, nor with 2 monoclonal antibodies reacting with neuronal cell surface glycoproteins related to the L2/HNK-1 family. These results show that AMOG is indeed a ligand in adhesion and binds to particular subpopulations of neurons in L1- and N-CAM-independent mechanisms.

We have recently charactcrizcd a novel adhesion molecule on glia, designated AMOG, which mediates neuron-astrocyte, but not astrocyte-astrocyte adhesion in vitro (Antonicek et al., 1987). In situ, AMOG is expressed in the developing cerebellum by Bergmann glial cells at the critical stages of granule neuron migration, which appears to involve surface contacts between migrating neurons and Bergmann glia. AMOG is undetectable on Bergmann glia by indirect immunoelectron microscopy before the onset and after the cessation of granule cell migration. In an in vitro assay system designed to probe for migration of granule cells in the early postnatal cerebellar cortex (Lindner et al., 1983), Fab fragments of monoclonal AMOG antibody inhibit granule cell migration by about $35 \%$, probably by dis-

\footnotetext{
Received Sept. 1, 1987; revised Nov. 30, 1987; accepted Dec. 3, 1987.

The authors are grateful to Deutsche Forschungsgemeinschaft (SFB 317) for support.

Correspondence should be addressed to Melitta Schachner, Department of Neurobiology, University of Heidelberg, Im Neuenheimer Feld 364, 6900 Heidelberg, FRG.

Copyright (C) 1988 Society for Neuroscience $0270-6474 / 88 / 082961-06 \$ 02.00 / 0$
}

turbing neuron-glia adhesion. By the time granule cell migration ceases, AMOG is more strongly expressed by astrocytes in the internal granular layer, where it remains detectable in adulthood. AMOG is an integral cell surface glycoprotein of $M_{\mathrm{r}} 45$ $50 \mathrm{kDa}$, containing at least $30 \% \mathrm{~N}$-glycosidically linked carbohydrate chains. AMOG does not belong to the L2/HNK-1 family of neural cell adhesion molecules (Kruse et al., 1984), which encompasses the neuron adhesion molecule L1 (Rathjen and Schachner, 1984), the neural cell adhesion molecule N-CAM (Edelman, 1986; Rutishauser and Goridis, 1986), the myelinassociated glycoprotein (MAG) (Poltorak et al., 1987), and the extracellular matrix adhesion molecule J1 (Kruse et al., 1985), but expresses another carbohydrate epitope, designated L3, that it shares with the adhesion molecules L1 and MAG (Kücherer et al., 1987). Although AMOG was designated an adhesion molecule, because Fab fragments of antibodies directed against it inhibited neuron-astrocyte adhesion in vitro, direct evidence to prove this point was missing. We therefore attempted to find conditions that allowed the incorporation of AMOG in functionally active form into artificial lipid vesicles. Here we show that $A M O G$ is indeed a ligand in cell adhesion and binds to some, but not all, neuronal cell types.

\section{Materials and Methods}

Animals. NMRI mice were obtained from Zentrale Tierzuchtanlage (Hannover, FRG), and maintained at the animal facilities of the Department of Neurobiology.

Antibodies. Monoclonal antibody to AMOG was obtained as described previously (Antonicek et al., 1987). The production and specificity of polyclonal antibodies to L1 and N-CAM have also been described (Faissner et al., 1984; Rathjen and Schachner, 1984; Bock et al., 1985). Monoclonal L3 antibody was described by Kücherer and colleagues (1987). IgG fractions from rabbit and rat antisera were obtained according to Fahey and Terry (1979). Fab fragments of monoclonal AMOG antibody were prepared with mercuripapain (Sigma) according to Porter (1959). Monovalent fragments or fragments with a reduced valency of $\mathrm{L} 3$ monoclonal antibody (rat $\mathrm{IgM}$ ) were prepared by tryptic digest (10 $\mu \mathrm{g} / \mathrm{ml}$ TPCK-trypsin) (type XIII; Sigma) in 150 $\mathrm{mM} \mathrm{NaCl}, 50 \mathrm{~mm}$ Tris, $20 \mathrm{mM} \mathrm{CaCl}, \mathrm{pH} 8.0$ ) for $5 \mathrm{hr}$ according to Matthew and Reichardt (1982).

Cell cultures. Monolayer cultures of cerebella from 6-d-old mice were prepared by a combination of enzymatic and mechanical dissociation and maintained as described previously (Schnitzer and Schachner, 1981). Small cerebellar neurons were obtained from 6 -d-old mice by centrifugation $\left(1200 \times g\right.$ for $10 \mathrm{~min}$ at $\left.4^{\circ} \mathrm{C}\right)$ through Percoll (Pharmacia), $40.5 \%$ in $\mathrm{Ca}^{2+}$ - and $\mathrm{Mg}^{2+}$-free Hanks' balanced salt solution containing $10 \mathrm{~mm}$ HEPES and $0.1 \%$ bovine serum albumin, $\mathrm{pH} 7.2$ (Keilhauer et al., 1985). Cells were washed free of Percoll in culture medium (Schnitzer and Schachner, 1981) and seeded on poly-L-lysine-coated coverslips at a density of $2 \times 10^{5}$ in $100 \mu$ l culture medium per coverslip. Cultures of spinal cord from 13-15-d-old mouse embryos and dorsal root ganglia from 1-d-old mice were prepared as described (Poltorak et al., 1987).

Isolation of AMOG by immunoaffinity chromatography. For the iso- 


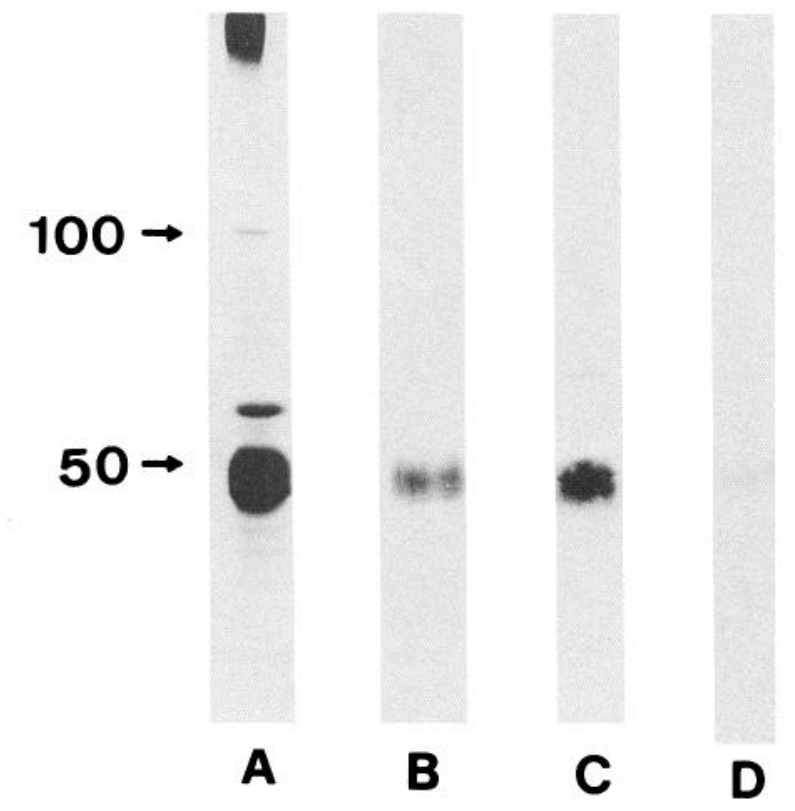

Figure 1. Demonstration of AMOG incorporation into liposomes. Lane $A$, immunoaffinity-purified AMOG isolated by elution from the monoclonal antibody column with $4 \mathrm{M} \mathrm{MgCl}_{2}$ and $1 \%$ octylglucoside; reducing silver stain. Lane $B$, immunoaffinity-purified AMOG (lane A) after incorporation into liposomes; reducing silver stain. Lane $C$, immunoaffinity-purified AMOG (lane A) after incorporation into liposomes; Western blot with polyclonal antibodies directed against immunoaffinity-purified AMOG (lane A). Lane $D$, immunoaffinity-purified AMOG (lane A) after incorporation into liposomes; Western blot with monoclonal L3 antibodies.

lation of AMOG, crude membrane fractions were prepared from adult mouse brains by homogenization in hypotonic buffer, as described (Rathjen and Schachner, 1984). Membranes were collected after a first centrifugation step to remove cell nuclei by centrifugation at $30,000 \times$ $g$ for $45 \mathrm{~min}$ at $4^{\circ} \mathrm{C}$. The pellet was resuspended in solubilization buffer (150 mm NaCl, $20 \mathrm{~mm}$ Tris, $1 \mathrm{~mm}$ EDTA, 1 mm EGTA, 1\% Na-cholate (Sigma), $5 \mathrm{~mm}$ iodoacetamide, $2 \mathrm{~mm}$ soybean trypsin inhibitor, and 5 $\mathrm{mm}$ phenylmethyl sulfonylfluoride, $\mathrm{pH} 7.5$ ) containing $5 \mathrm{mg} / \mathrm{ml} \mathrm{L}$ $\alpha$-phosphatidylcholine from soybean (type IV-S; Sigma). After $2 \mathrm{hr}$ stirring on ice, detergent-insoluble material was removed by centrifugation at $100,000 \times g$ for $1 \mathrm{hr}$ at $4^{\circ} \mathrm{C}$. The supernatant was first added to a Sepharose 4B-immunoglobulin column with IgG isolated from nonimmune rats immobilized according to Stoeckl et al. (1976). The run-through was passed over a monoclonal AMOG antibody column $(5 \mathrm{ml}$ of gel matrix volume with an $\mathrm{IgG}$ concentration of $5.6 \mathrm{mg} / \mathrm{ml}$ of gel matrix). The column was washed consecutively with $250 \mathrm{ml}$ solubilization buffer containing $5 \mathrm{mg} / \mathrm{ml} \mathrm{L}$ - $\alpha$-phosphatidylcholine, $20 \mathrm{ml}$ PBS (pH 7.3), $100 \mathrm{ml}$ of $20 \mathrm{~mm}$ Tris buffer (pH 7.4) containing $1 \mathrm{~m}$ $\mathrm{NaCl}$, and, finally, $50 \mathrm{ml} \mathrm{PBS}$. Bound material was first eluted from the column with $25 \mathrm{ml}$ of $4 \mathrm{M} \mathrm{MgCl}_{2}$ containing $1 \% n$-octylglucoside (Sigma), then with $25 \mathrm{ml}$ of $0.1 \mathrm{M}$ diethylamine, $1 \mathrm{~mm}$ EDTA, $1 \mathrm{~mm}$ EGTA, and $0.1 \%$ Na-deoxycholate, $\mathrm{pH} 11.5$. The second eluate was immediately neutralized by addition of $1 \mathrm{~m}$ Tris buffer, $\mathrm{pH} 6.8$. The first eluate, which contained about two-thirds of the total bound material, was dialyzed extensively against double-distilled water for 24-36 hr and then against solubilization buffer containing $1 \% n$-octylglucoside for $36-48$ $\mathrm{hr}$. The second eluate was dialyzed for $48 \mathrm{hr}$ against solubilization buffer containing $0.5 \% \mathrm{Na}$-cholate or $1 \%$ octylglucoside. Both eluates were concentrated by pressure dialysis through Amicon filters to a final concentration of $200-500 \mu \mathrm{g} / \mathrm{ml}$. The yield of AMOG was $1 \mathrm{mg} / 100 \mathrm{~g}$ net weight of adult mouse brain. The purity of both eluates was comparable (not shown).

Preparation of lipid vesicles (liposomes). For reconstitution into lipid vesicles, $100 \mu \mathrm{g}$ of immunoaffinity-purified AMOG was mixed with 220 $\mu \mathrm{g}$ cholesterol (Fluka) and $780 \mu \mathrm{g}$ egg yolk phosphatidylcholine (type XI-E; Sigma) in $1 \mathrm{ml}$ of $10 \mathrm{~mm}$ Tris, $75 \mathrm{~mm} \mathrm{NaCl}$, pH 7.4, containing $91 \mathrm{~mm}$ octylglucoside and $40 \mathrm{~mm}$ carboxyfluorescein. After $2 \mathrm{hr}$ at room temperature, the detergent was removed by dialysis against Tris-buffered saline (TBS; $150 \mathrm{~mm} \mathrm{NaCl}, 20 \mathrm{~mm}$ Tris, $\mathrm{pH} \mathrm{7.4)} \mathrm{by} \mathrm{diluting} \mathrm{the} \mathrm{deter-}$ gent-containing solution by the addition of 45 volumes of half-strength TBS, followed by dialysis against TBS or by chromatography on a Sephadex-G25 column $(27 \mathrm{ml})$ of which $11 \mathrm{ml}$ were occupied with $40 \mathrm{~mm}$ carboxyfluorescein in TBS, followed by dialysis against TBS for $48 \mathrm{hr}$ at $4^{\circ} \mathrm{C}$. Liposomes were separated from unbound protein by sucrosegradient centrifugation (Sadoul et al., 1983) and dialyzed against 0.15 $\mathrm{M} \mathrm{NaCl}, 20 \mathrm{~mm}$ HEPES, $\mathrm{pH} 7.2$, for $24 \mathrm{hr}$, also at $4^{\circ} \mathrm{C}$. The incorporated protein was analyzed by SDS-PAGE according to Laemmli (1970), using the reducing silver method of Merril and colleagues (1982) or Western blot analysis according to Towbin and colleagues (1979), with the modifications of Faissner et al. (1984).

Liposome binding to cell cultures. Monolayer cultures were incubated in blocking buffer (Dulbecco's PBS-DPBS-containing 10\% horse serum and $1 \%$ bovine serum albumin) for $15 \mathrm{~min}$ at room temperature. Liposomes were diluted 1:10-1:50 in blocking buffer and added to the cells on coverslips ( $50 \mu \mathrm{l} /$ coverslip). After $1 \mathrm{hr}$ of incubation at room temperature, cells were washed 3 times in DPBS and mounted in Mowiol (Hoechst). To test for the specificity of liposome binding, 3 sets of experiments were performed. First, liposomes without AMOG were incubated with cells, as described for AMOG-containing liposomes. Second, AMOG-containing liposomes were diluted in blocking buffer and incubated at $4^{\circ} \mathrm{C}$ in the presence of monovalent fragments of antibodies to AMOG (Fabs) and L3 (see Antibodies, above). After $1 \mathrm{hr}$, the suspension was added to the monolayer cultures and liposome binding was monitored as described. Third, cell cultures were incubated with several mono- and polyclonal antibodies, including mono- and polyclonal antibodies against AMOG, monoclonal antibody L3, monoclonal antibodies 487 and 483 (both reacting with cell surfaces of neurons in culture; unpublished observations), polyclonal $\mathrm{L} 1$, and polyclonal N-CAM antibodies. After $30 \mathrm{~min}$ at room temperature, unbound antibodies were removed by washing once and liposomes added and incubated as described above.

\section{Results and Discussion}

\section{Preparation of functionally active AMOG-containing liposomes}

When AMOG was isolated by immunoaffinity chromatography after solubilization of crude membrane fractions with $1 \%$ NP40 and elution from the monoclonal antibody column by $0.1 \mathrm{M}$ diethylamine, $\mathrm{pH} 11.5$, in the presence of $0.5 \%$ deoxycholate (Antonicek et al., 1987), it was incorporated into cholesteroland phosphatidylcholine-containing liposomes, but no binding to monolayer cells from cerebellum or spinal cord was observed. By varying several parameters in the isolation of AMOG and in the preparation of the liposomes, a protocol was obtained (see Materials and Methods) that resulted in AMOG-containing liposomes that were functionally active in cell binding (see below). The parameters crucial for obtaining these functionally competent liposomes were solubilization of membrane fractions in $1 \% \mathrm{Na}$-cholate for $2 \mathrm{hr}$ on ice in the presence of soybean lecithin, elution of AMOG from the monoclonal antibody column in $4 \mathrm{M} \mathrm{MgCl}_{2}$ in the presence of $1 \%$ octylglucoside, and removal of octylglucoside during incorporation of $\mathrm{AMOG}$ into liposomes by gel filtration over Sephadex-G25. AMOG-containing liposomes had a tendency to aggregate and always had to be segregated before each binding test by rigorous pipetting.

To verify that AMOG that was isolated according to the modified procedure was biochemically comparable to AMOG isolated as previously described (Antonicek et al., 1987), and to prove that AMOG indeed incorporated into liposomes as a 50 kDa glycoprotein, it was analyzed by SDS-PAGE before and after incorporation into liposomes (Fig. 1). AMOG could be isolated by the modified procedure with a degree of purity similar to that produced by previously described purification procedures (Fig. 1, lane A; also, compare with Fig. 4 in Antonicek et al., 1987). As previously observed, the $50 \mathrm{kDa}$ band could 

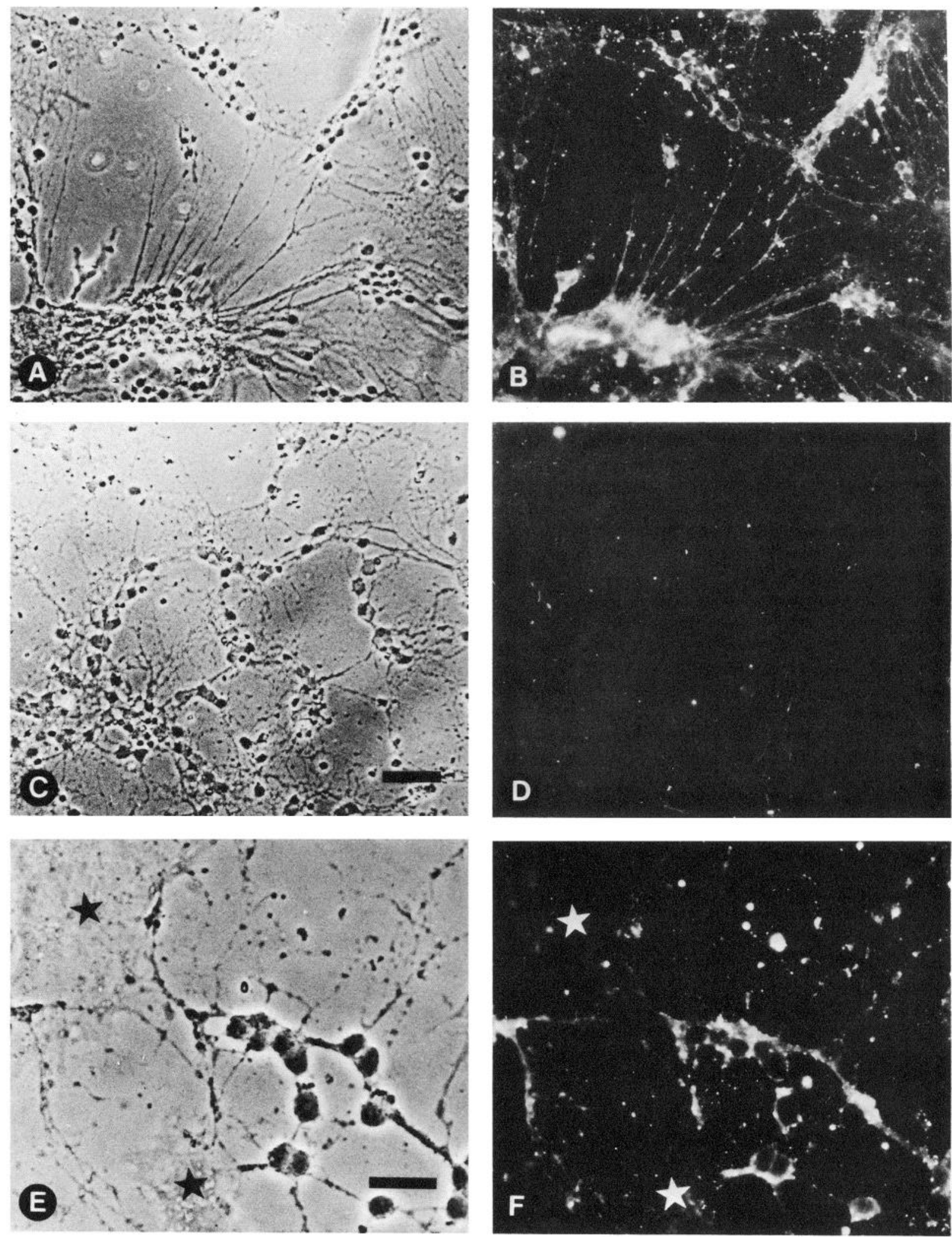

Figure 2. Binding of carboxyfluorescein-labeled liposomes with $(B, F)$ and without $(D)$ incorporated immunoaffinity-purified AMOG (see Fig. 1) in monolayer cultures of early postnatal mouse cerebellum after $4 \mathrm{~d}$ in vitro. $A, C, E$, The corresponding phase-contrast micrographs to fluorescence images $B, D$, and $F$, respectively. Liposomes without protein do not show binding $(C, D)$, whereas AMOG-containing liposomes show binding to small cerebellar neurons $(A, B$, and $E, F)$. Epithelioid cells (asterisks, $E, F)$ were not recognized by AMOG-containing liposomes when binding to cell-free substrate was taken as background. Bar in $C, 50 \mu \mathrm{m}(A-D)$; bar in $E, 30 \mu \mathrm{m}(E, F)$. 

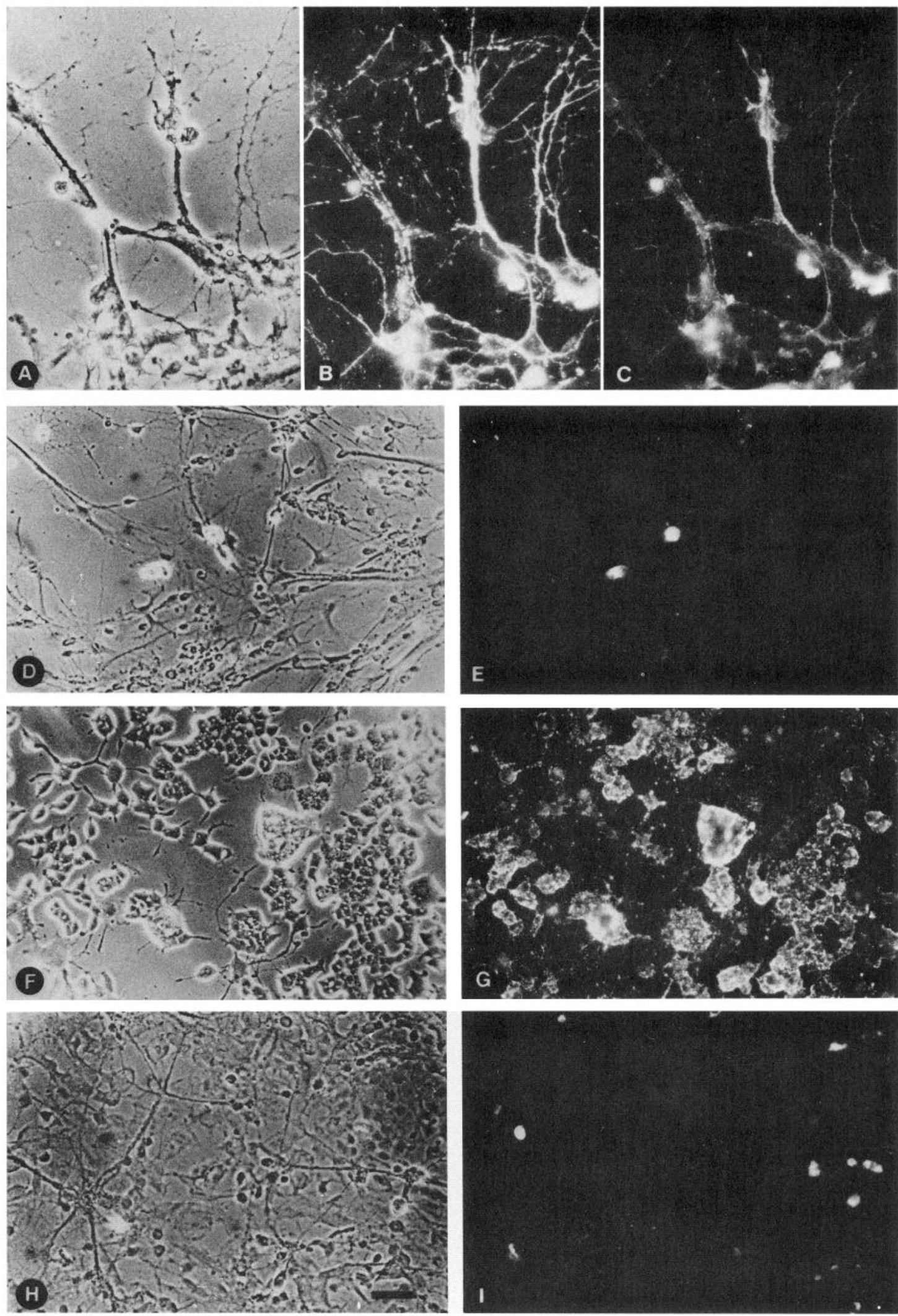

Figure 3. Double-immunofluorescence staining of monolayer cultures of early postnatal mouse cerebellum after $4 \mathrm{~d}$ in vitro, using polyclonal antibodies against $\mathrm{L1}(B$, using tetramethyl rhodamine-coupled second antibodies) and carboxyfluorescein-labeled AMOG-containing liposomes $(C)$. When liposomes are preincubated with Fab fragments of monoclonal AMOG antibody, binding of AMOG-containing liposomes to cerebellar cells is blocked $(E)$. AMOG-containing liposomes bind to cultured pheochromocytoma PC12 cells $(G)$. AMOG-containing liposomes do not bind to cultures of embryonic mouse spinal cord after $10 \mathrm{~d}$ in vitro $(I) . A, D, F, H$, The phase-contrast micrographs corresponding to fluorescence images $B$ and $C$ and $E, G$, and $I$, respectively. Bar in $H, 50 \mu \mathrm{m}$. 
not be isolated in pure form, but was always contaminated with other bands with higher molecular weights. When this preparation was used to prepare AMOG-containing liposomes, a predominant band at $50 \mathrm{kDa}$ was found to be incorporated into the liposomes (Fig. 1, lane B). To further verify the purity of AMOG incorporated into liposomes, the more sensitive Western blot analysis was performed with polyclonal antibodies prepared against the AMOG preparation containing the several contaminating bands (see Antonicek et al., 1987). These antibodies, reacting not only with the $50 \mathrm{kDa}$, but also with the other, higher-molecular-weight components, detected only the $50 \mathrm{kDa}$ component in the AMOG-containing liposomes (Fig. 1, lane C). AMOG incorporated into liposomes also contained the L3 carbohydrate epitope (Fig. 1, lane D) that is characteristic of AMOG (Antonicek et al., 1987).

\section{Binding of liposomes to monolaver cultures}

To investigate whether AMOG-containing liposomes could bind to monolayer cultures of live cells, several types of cultures were used. In cultures obtained from 6-d-old mouse cerebellum maintained for 3-10 d in vitro, binding of AMOG-containing liposomes was seen (Figs. 2, $A, B, E, F ; 3, A-C$ ). Binding was both to cell bodies and processes of neurons, as identified by their expression of the neural cell adhesion molecule L1 (Figs. 3, A-C). Binding of AMOG-containing liposomes was never uniform and continuous over cell body or neurites. AMOGcontaining liposomes bound to most, if not all, small cerebellar neurons and did not bind to any other cell types present in the cerebellar cultures (as compared to nonspecific binding to cellfree substrate taken as background), i.e., $\mathrm{O}_{4}$ antigen expressing oligodendrocytes, astrocytes, or fibronectin-positive fibroblasts or fibroblast-like cells (see epithelioid cells marked by asterisks in Fig. 2, E, F). In cultures of pure, small neurons from 6-dold mouse cerebella maintained up to $14 \mathrm{~d}$ in vitro, binding of AMOG-containing liposomes was not observed after $1 \mathrm{~d}$ in vitro, was rarely detectable after $2 \mathrm{~d}$, was readily detectable after $3 \mathrm{~d}$, and remained detectable, with apparently similar binding "intensities," thereafter.

Binding specificity of AMOG-containing liposomes to neurons was investigated in 2 ways. First, carboxyfluorescein-labeled liposomes without protein were incubated with monolayer cultures exactly as were AMOG-containing liposomes, and did not show any detectable levels of binding (Fig. 2, $C, D$ ). Furthermore, preincubation of AMOG-containing liposomes for 1 hr at $4^{\circ} \mathrm{C}$ with Fab fragments or total $\operatorname{IgG}$ fractions of monoclonal AMOG antibodies resulted in complete inhibition of liposome binding (Fig. 3, D, E). Preincubation of liposomes with monovalent fragments of monoclonal antibodies directed against the L3 carbohydrate structure did not show any inhibition of liposome binding. However, since only a subpopulation of AMOG molecules was found to express the L3 epitope (Kücherer et al., 1987) and since estimation of the binding efficacies of liposomes is only qualitative, the question of involvement of the $\mathrm{L} 3$ carbohydrate structure in the adhesion of $\mathrm{AMOG}$ remains open.

To investigate whether all types of neurons expressed the receptor(s) for AMOG, cultures of spinal cord, dorsal root ganglia, and PC12 pheochromocytoma cells were assayed. In cultures of spinal cord from 13-15-d-old mouse embryos maintained for 7-21 d in vitro and in cultures of dorsal root ganglia from 13-15-d-old mouse embryos maintained for 5-14 d in vitro, no binding of AMOG-containing liposomes was observed (for spinal cord cultures, see Fig. 3, $H, I$ ). $\Lambda \mathrm{MOG}$-containing liposomes bound well to undifferentiated PC12 pheochromocytoma cells in culture (Fig. 3, F, G). Interestingly, liposomes did not bind with equal "intensity" to all cells, suggesting a heterogeneity in receptor(s) for AMOG.

\section{Other adhesion molecules are not receptors for $A M O G$}

To investigate whether any of the known adhesion molecules that are expressed on neurons may be the receptors for AMOG, monolayer cultures of early postnatal mouse cerebellum were preincubated with antibodies to several cell adhesion molecules prior to addition of AMOG-containing liposomes. None of the antibodies investigated inhibited binding of AMOG-containing liposomes to neurons (not shown). These antibodies were directed against $\mathrm{L} 1, \mathrm{~N}-\mathrm{CAM}$, and newly discovered cell surface glycoproteins on neurons, designated, at present, 483 and 487 . Also, preincubation of cells with mono- and polyclonal AMOG antibodies prior to addition of AMOG-containing liposomes did not reduce binding of AMOG-containing liposomes to neurons, suggesting that AMOG is not involved in a "homophilic," but a "heterophilic," binding mechanism.

\section{Conclusions}

These experiments show that AMOG is indeed a ligand in cell adhesion, and thus, by operational definition, an adhesion molecule. Our experiments also substantiate previous predictions that AMOG is involved in "heterophilic" binding mechanisms. None of the previously recognized adhesion molecules on neurons, i.e., L1, N-CAM, 483, or 487, seem to be the putative "heterophilic" receptors for AMOG. The absence of AMOG receptors on neurons from spinal cord and dorsal root ganglia at several developmental stages is noteworthy. It is unlikely that these neurons are not competent to express receptors for AMOG in our cultures, since these neurons develop receptors for the MAG in a developmental sequence reminiscent of the in vivo situation (R. Sadoul, unpublished observations). Furthermore, AMOG and MAG show inverse binding specificities to neurons: whereas MAG binds well to neurons of spinal cord and dorsal root ganglia and weakly to granule cells (Poltorak et al., 1987), AMOG binds well to granule cells and not to spinal cord and dorsal root ganglion neurons. The unique distribution of these receptors on some neurons, but not on others, underscores the functional singularity of AMOG in granule cell neuron-astrocyte interactions in the developing cerebellum (Antonicek et al., 1987). The observation that PC12 pheochromocytoma cells show a strong, although not uniform, expression of AMOG receptor(s) is curious and, at present, unexplained, but encourages attempts to isolate the receptor(s).

\section{References}

Antonicck, H., E. Persohn, and M. Schachncr (1987) Biochemical and functional characterization of a novel neuron-glia adhesion molecule that is involved in neuronal migration. J. Cell Biol. 104: 1587-1595.

Bock, E., C. Richter-Landsberg, A. Faissner, and M. Schachner (1985) Demonstration of immunochemical identity between the nerve growth factor-inducible large external (NILE) glycoprotein and the cell adhesion molecule L1. EMBO J. 4: 2765-2768.

Edelman, G. (1986) Cell adhesion molecules in neural histogenesis. Annu. Rev. Physiol. 48: 417-430.

Fahey, J. L., and E. W. Terry (1979) Ion exchange chromatography and gel filtration. In Handbook of Experimental Immunology, D. M. Weir, ed., pp. 19-43, Blackwell, Oxford, UK.

Faissner, A., J. Kruse, C. Goridis, E. Bock, and M. Schachner (1984) The neural cell adhesion molecule Ll is distinct from the N-CAM 
related group of surface antigens BSP-2 and D2. EMBO J. 3: $733-$ 737.

Keilhauer, G., A. Faissner, and M. Schachner (1985) Differential inhibition of neurone-neurone, neurone-astrocyte and astrocyte-astrocyte adhesion by L1, L2 and N-CAM antibodies. Nature 316: 728 730.

Kruse, J., R. Mailhammer, H. Wernecke, A. Faissner, I. Sommer, C. Goridis, and M. Schachner (1984) Neural cell adhesion molecules and myelin-associated glycoprotein share a common carbohydrate moiety recognized by monoclonal antibodies L2 and HNK-1. Nature 311: 153-155.

Kruse, J., G. Keilhauer, A. Faissner, R. Timpl, and M. Schachner (1985) The $\mathbf{J} 1$ glycoprotein - a novel nervous system cell adhesion molecule of the L2/HNK-1 family. Nature 316: 146-148.

Kücherer, A., A. Faissner, and M. Schachner (1987) The novel carbohydrate epitope L3 is shared by some neural cell adhesion molecules. J. Cell Biol. 104: 1597-1602.

Laemmli, U.K. (1970) Cleavage of structural proteins during the assembly of the head of bacteriophage T4. Nature 227: 680-685.

Lindner, J., F. G. Rathjen, and M. Schachner (1983) L1 mono- and polyclonal antibodies modify cell migration in early postnatal mouse cerebellum. Nature 305: 427-430.

Matthew, W. D., and L. F. Reichardt (1982) Development and application on an efficient procedure for converting mouse IgM into small, active fragments. J. Immunol. Methods 50: 239-253.

Merril, C. R., D. Goldman, and M. C. Van Keuren (1982) Simplified silver protein detection and image enhancement methods in polyacrylamide gels. Electrophoresis 3: 17-23.
Poltorak, M., R. Sadoul, G. Keilhauer, C. Landa, T. Fahrig, and M. Schachner (1987) The myelin-associated glycoprotein (MAG), a member of the L2/HNK-1 family of neural cell adhesion molecules, is involved in neuron-oligodendrocyte and oligodendrocyte-oligodendrocyte interaction. J. Cell Biol. 105: 1893-1899.

Porter, R. R. (1959) The hydrolysis of rabbit gamma-globulin and antibodies with crystalline papain. Biochem. J. 73: 119-131.

Rathjen, F. G., and M. Schachner (1984) Immunocytological and biochemical characterization of a new neuronal cell surface component (L1 antigen) which is involved in cell adhesion. EMBO J. 3: 110.

Rutishauser, U., and C. Goridis (1986) N-CAM: The molecule and its genetics. Trends Genet. 2: 72-76.

Sadoul, R., M. Hirn, H. Deagostini-Bazin, G. Rougon, and C. Goridis (1983) Adult and embryonic forms of a mouse neural cell adhesion molecule have different binding properties. Nature 304: 347-348.

Schnitzer, J., and M. Schachner (1981) Expression of Thy-1, H-2, and NS-4 cell surface antigens and tetanus toxin receptors in early postnatal and adult mouse cerebellum. J. Neuroimmunol. I: 429-456.

Stoeckl, K., C. Gagnon, G. Guroff, and H. Thoenen (1976) Purification of nerve growth factor antibodies by affinity chromatography. J. Neurochem. 26: 1207-1211.

Towbin, H., T. Staehelin, and J. Gordon (1979) Electrophoretic transfer of proteins from polyacrylamide gels to nitrocellulose sheets: Procedure and some applications. Proc. Natl. Acad. Sci. USA 76: 43504354. 